\title{
Corrigendum: Deficiency of UBR1, a ubiquitin ligase of the N-end rule path- way, causes pancreatic dysfunction, malformations and mental retardation (Johanson-Blizzard syndrome)
}

Martin Zenker, Julia Mayerle, Markus M Lerch, Andreas Tagariello, Klaus Zerres, Peter R Durie, Matthias Beier, Georg Hülskamp, Celina Guzman, Helga Rehder, Frits A Beemer, Ben Hamel, Philippe Vanlieferinghen, Ruth Gershoni-Baruch, Marta W Vieira, Miroslav Dumic, Ron Auslender, Vera L Gil-da-Silva-Lopes, Simone Steinlicht, Manfred Rauh, Stavit A Shalev, Christian Thiel, Arif B Ekici, Andreas Winterpacht, Yong Tae Kwon, Alexander Varshavsky, and André Reis Nat. Genet. 37, 1345-1350 (2005).

The name of the 23rd author (Arif B. Ekici) has now been included in the author list. Arif B. Ekici is at the Institute of Human Genetics, University of Erlangen-Nuremberg, Schwabachanlage 10, 91054 Erlangen, Germany. 